\title{
Archaeological Survey and Testing for Mission County Park, San Antonio, Bexar County, Texas
}

I. Waynne Cox

Follow this and additional works at: https://scholarworks.sfasu.edu/ita

Part of the American Material Culture Commons, Archaeological Anthropology Commons, Environmental Studies Commons, Other American Studies Commons, Other Arts and Humanities Commons, Other History of Art, Architecture, and Archaeology Commons, and the United States History Commons

Tell us how this article helped you.

This Article is brought to you for free and open access by the Center for Regional Heritage Research at SFA ScholarWorks. It has been accepted for inclusion in Index of Texas Archaeology: Open Access Gray Literature from the Lone Star State by an authorized editor of SFA ScholarWorks. For more information, please contact cdsscholarworks@sfasu.edu. 


\section{Archaeological Survey and Testing for Mission County Park, San Antonio, Bexar County, Texas}

\section{Creative Commons License}

\section{(c) (1) \&}

This work is licensed under a Creative Commons Attribution-NonCommercial 4.0 International License 


\section{ARCHAEOLOGICAL SURVEY AND TESTING FOR MISSION COUNTY PARK, SAN ANTONIO, BEXAR COUNTY, TEXAS}

I. Waynne Cox

Texas Antiquities Committee Permit No. 769

Jack D. Eaton, Principal Investigator

Center for Archaeological Research

The University of Texas at San Antonio®

Archaeological Survey Report, No. 190 
The following information is provided in accordance with the General Rules of Practice and Procedure, Chapter 41.11 (Investigative Reports), Texas Antiquities Committee:

1. Type of investigation: archaeological survey and testing;

2. Project name: Mission County Park;

3. County: Bexar;

4. Principal investigator: Jack D. Eaton, coprincipal investigator: Anne A. Fox;

5. Name and location of sponsoring agency: Bexar County Parks Department, San Antonio, Texas;

6. Texas Antiquities Committee Permit No. 769;

7. Published by the Center for Archaeological Research, The University of Texas at San Antonio, San Antonio, Texas 78285-0658, 1989.

A list of publications offered by the Center for Archaeological Research can be obtained by sending $\$ 1.00$ to the Center for Archaeological Research, The University of Texas at San Antonio, San Antonio, Texas 78285-0658. 


\begin{abstract}
In May 1989, a team of archaeologist and volunteers from the Center for Archaeological Research performed a 100\% survey and selective shovel testing on a tract of land intended for an expansion of Mission County Park. The survey and testing revealed that the area was either old river channel or under extensive spoil from the rechannelization of the San Antonio River. No archaeological or historical cultural resources were encountered.
\end{abstract}




\section{TABLE OF CONTENTS}

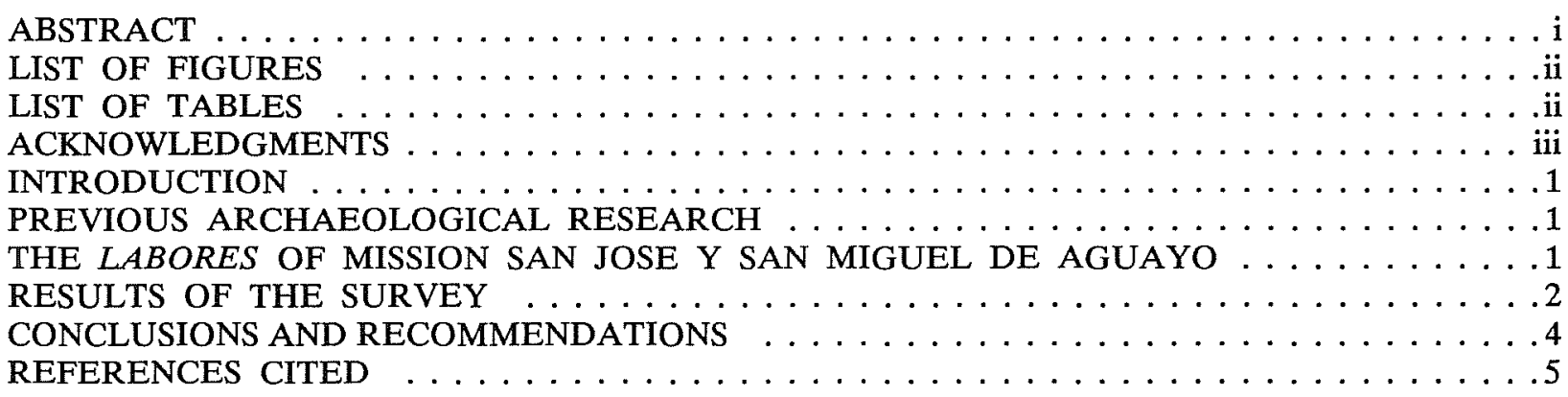

\section{LIST OF FIGURES}

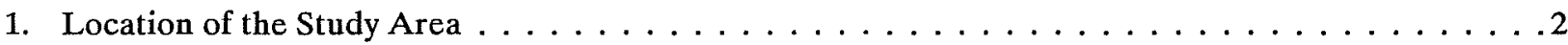

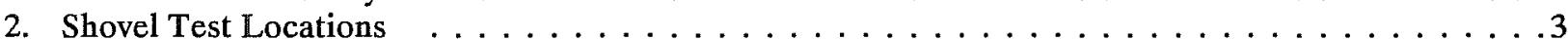

\section{LIST OF TABLES}

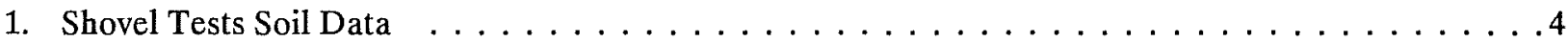




\section{ACKNOWLEDGMENTS}

I wish to express my appreciation to the members of the staff that assisted in this survey, Anne Fox, Lynn Highley, Maureen Brown, and Frances Meskill. Frances also produced the illustrations for this report. In addition to the staff, I am indebted to our volunteers, Burnley "Duke" Smith, Herbert Allison, Tommy Tomesal, Marty Morrison, and Laura Andrew. John Ogden Leal, county archivist, also rendered his assistance in the research of the history. A debt of gratitude is also due to the late Fr. Marion A. Habig, O.F.M., for his outstanding research on the San Antonio missions. 



\section{INTRODUCTION}

In March 1989, the Center for Archaeological Research, The University of Texas at San Antonio (CAR-UTSA) entered into a contract with the Bexar County Parks Department, San Antonio, Texas (letter from M. David Cervantez, dated May 3, 1989) to provide an archaeological survey of the Mission County Park site in south San Antonio, Texas. The total area involved for the survey was approximately 40 acres. The contract required the Center to conduct a $100 \%$ visual survey supplemented by shovel testing to probe beneath the surface as deemed necessary. The survey was conducted in May 1989 by a team of five archaeologists and several experienced volunteers over a period of five days. I. Waynne Cox was the project director. All project work was done under the general supervision of Jack D. Eaton, Center acting director. All photographs, files, and other pertinent information concerning this project are curated at the CAR-UTSA.

\section{PREVIOUS ARCHAEOLOGICAL RESEARCH}

When the original 36 acres of Mission County Park were acquired in 1951, there was no legal requirement for archaeological investigation, nor was any performed. However, there have been numerous investigations directed toward nearby Mission San José y San Miguel de Aguayo, 41 BX 3 (Fox 1970; Schuetz 1970; Clark 1978). The establishment of the Mission Parkway prompted a thorough archival investigation and survey by the Texas Historical Commission of the area under consideration (Scurlock et al. 1976). In 1984, the CAR investigated the historic Hot Wells site, $41 \mathrm{BX} 237$, directly to the east across the San Antonio River (Fox and Highley 1985). In 1988, the CAR relocated and investigated the San Juan Dam, 41 BX 266, also on the east bank of the San Antonio River and south of the Mission County Park site (Hafernik, Cox, and Fox 1989).

\section{THE LABORES OF MISSION SAN JOSE Y SAN MIGUEL DE AGUAYO}

March 13, 1720, Captain Juan Valdéz, accompanied by Father Margil and an official party, progressed along the meanders of the San Antonio River "a little more than three leagues" from Mission San Antonio de Valero and established Mission San José y San Miguel de Aguayo upon its first site (Valdéz 1720). The Royal orders required that all missions be separated by at least three leagues (nine miles) to insure sufficient labores of farmland to meet their needs. By measuring the distance along the meanders of the river, rather than as the crow flies, Mission San José was founded closer to the first mission (Valero) than normally would have been the case.

It is quite clear from the initial reports that the first location for Mission San José was on the eastern bank of the San Antonio River. However, by 1730, Pedro de Rivera (1730) is quite definite in his placement of the mission on the west bank of the river, assuming that previous reports were in error. The second location was selected, for whatever reason, on the west bank a little farther down the river. This would place it somewhere in the general area of the park site. The mission was constructed of adobe, and an acequia was dug to serve its agricultural fields (Habig 1968:35). The mission grew and prospered at this location for at least a decade and then fell upon bad times. In 1739, an epidemic struck the San Antonio area, and the population of Mission San José fell to 95 Indians (Santa Ana 1740). Perhaps the high death toll at Mission San José was a result of its location on the low-lying land near the river. Whatever the reason, by 1740, Fray Nuñez had relocated the mission 25 feet higher and one-half miles farther to the west at its present location (Habig 1968:45).

The acequia that watered the lands of Mission San José at the second location began on the San Antonio River from a dam located a short distance south of the mouth of Concepcion Creek, then followed what is now Mission Road. At a point that is now approximately White Avenue, the acequia turned to the east to what is now Padre Drive and then turned south to rejoin the river at present-day Pyron Road. This branch, later referred to as the Acequia Media, was probably the original channel which was later diverted to serve the present location of the mission. All of the lands to the east of the acequia served as the labores or fields of the mission.

Upon secularization of the mission in 1793, the lands were divided into suertes and distributed to the mission Indians and other citizens of the Villa de Bejar. The parcel containing the park site was granted to Damino de la Cruz November 8, 1823. His grant reads:

There I surveyed one-half suerte of land with a frontage of 304 varas [ 844 feet] on the north, 225 varas [ 625 feet] on the south and a depth from the irrigation conduit to the river.

This land is bounded on the east by the river; on the north by the property of José Maria Ruiz; on the west by the irrigation conduit and on the south by Grapevine Corner and it is granted to him with the accompanying irrigation water (Spanish Deed Vol. 2:366). 
Damino de la Cruz and his wife Margarita del Toro, both Indians of Mission San José, were married September 3, 1804, and had nine children. After the death of Damino, Margarita married Tomas Cortez and had two children by him. Upon her death, in 1850, the property passed to the joint heirs, Melchora Cortez de Flores, Pedro Flores, Catarina Cortez Aguila, and Dolores Cortez (DR Vol. K2:526). They sold the property to John S. McClellan, who conveyed it to Roderick Higginbotham in 1855 (DR Vol. N1:211). The plot was later divided, and the southern half was purchased by Lucy O'Sullivan and the northern half by M. M. Neal and N. R. Cotton. The southern half was purchased, in 1895 , by Carlos Bee, son of the Confederate General Hamilton Bee. The Neal and Cotton property was first purchased by F. V. Anderson in 1900, and two years later resold to Lucy Quarles (DR Vol. 140:459, Vol. 145:576, Vol. 184:214, Vol. 185:446, Vol. 208:89). The property was later acquired by Elizabeth O. Graham and Thurman Barrett who, in 1951, donated a portion of the tract to the county to be dedicated and maintained as a park (DR Vol. 1372, Vol. 2991:224, 226). In 1977, Commissioners Court approved the purchase of additional land to be added to the park.

\section{RESULTS OF THE SURVEY}

The study area lies on the west bank of the San Antonio River to the east of the grounds of Mission San José (Fig. 1). The area was completely surveyed by walking over the area in 2-m transects and noting any cultural features or artifacts, and the surface character. The only artifacts observed were from the late 20th century, but the rechannelization of the river had greatly altered the tract. The old river channel was clearly visible by virtue of the old pecan trees along its banks and the lower area on the northern portion of the property (Fig. 2). Of particular interest was the path of the old Acequia Media that once ran through the area. No indication of it was found in the study area, but measurements from the deed plats enabled the team to locate it outside the park boundaries. It exists as a drainage ditch on the west side of Padre Drive beginning near White Avenue, passing under the road via a culvert and returning to the old river channel at Pyron Drive.

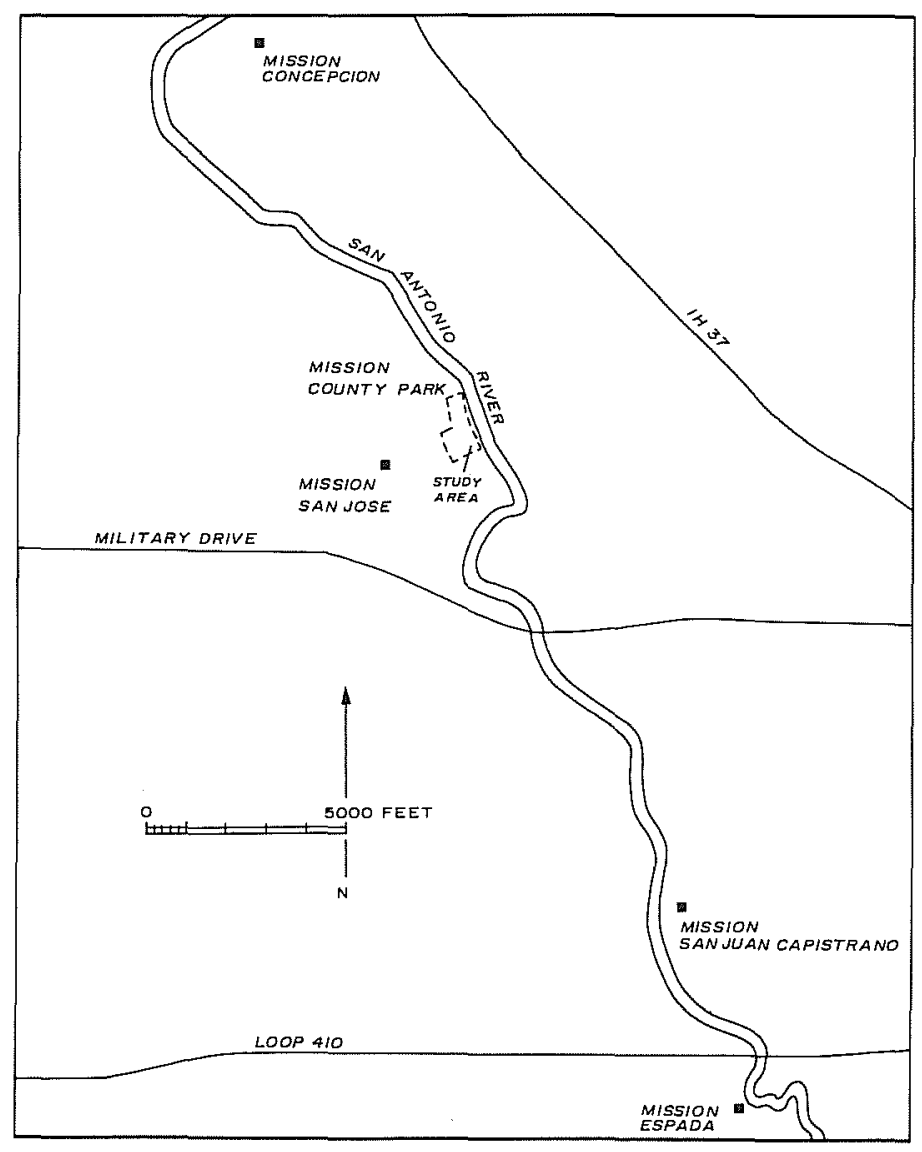

Figure 1. Location of the Study Area. 


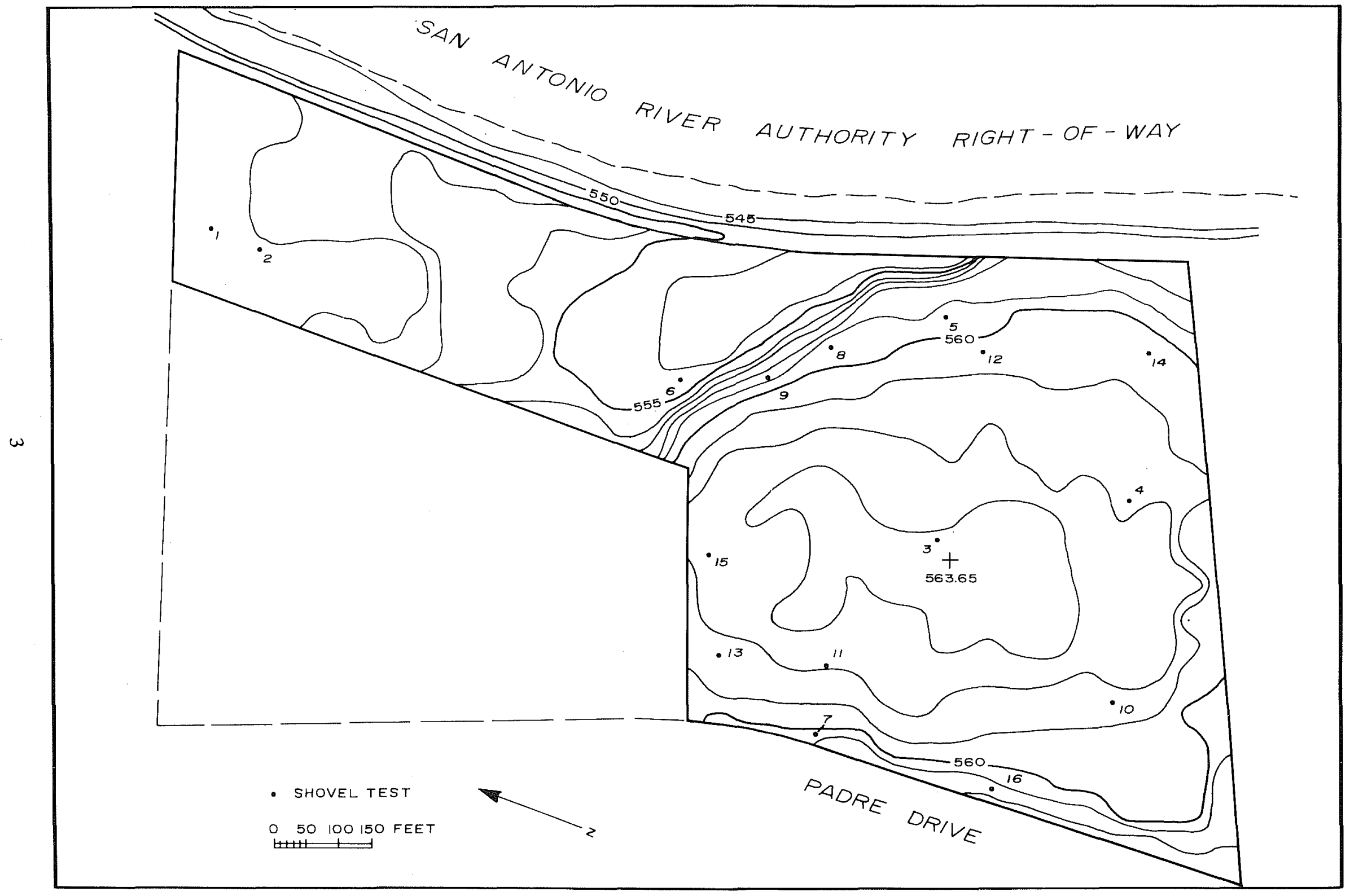

Figure 2. Shovel Test Locations. 
Failing to find any evidence of prehistoric or historic occupation by the survey, a series of 16 shovel tests was excavated throughout the park area in selected places (Fig. 2). The majority of the tests were concentrated in the southern one-half of the park area since the survey had established that the northern portion had been located in the old river channel. The shovel tests depth and the soils encountered in each test are recorded in Table 1.

\section{CONCLUSIONS AND RECOMMENDATIONS}

The shovel tests clearly indicated that the entire southern portion of the tract had been covered with a heavy layer of spoil as a result of the rechannelization of the river in the 1950s. Judging from the results of the shovel tests and the present land contours, the extent of the fill appeared to exceed three feet in depth. Therefore, the planned projected developments to the tract are not expected to disturb the area below that depth. The northern portion of the park is the old river channel, and as such, is void of any cultural remains. It consists entirely of fill. Since the Acequia Media was located to the west of Padre Drive, and therefore outside the park limits, it likewise will not be affected by the proposed construction. Therefore, no further archaeological work is recommended at this time. However, if future additions to the park exceed a depth of three feet from the original ground level, further archaeological investigations should be considered.

TABLE 1. SHOVEL TESTS SOILS DATA

\begin{tabular}{|c|c|c|c|}
\hline Number & $\begin{array}{c}\text { Below } \\
\text { Ground Surface }\end{array}$ & Munsell Code & Observations \\
\hline 1 & $0-30 \mathrm{~cm}$ & $2.5 \mathrm{Y} 4 / 2$ & Gray tan gravelly soil to sterile brown \\
\hline 2 & $0-50 \mathrm{~cm}$ & $2.5 Y 4 / 2$ & Gray tan gravelly soil to sterile brown \\
\hline $3 a$ & $0-35 \mathrm{~cm}$ & $5 Y 5 / 3$ & Light brown soil with small gravels \\
\hline $3 b$ & $35-50 \mathrm{~cm}$ & $5 Y 5 / 2$ & Yellow clay with large gravels \\
\hline 4 & $0-40 \mathrm{~cm}$ & $2.5 \mathrm{Y} 3 / 2$ & Dark grayish brown soil \\
\hline $5 a$ & $0-20 \mathrm{~cm}$ & $2.5 Y 5 / 2$ & Light brown soil with gravel \\
\hline $5 b$ & $20-31 \mathrm{~cm}$ & $2.5 \mathrm{Y} 5 / 2$ & Same with less gravel and a pull tab \\
\hline 6 & $0-30 \mathrm{~cm}$ & $2.5 Y \quad 4 / 2$ & Dark grayish brown soil \\
\hline 7 & $0-33 \mathrm{~cm}$ & $2.5 Y 3 / 2$ & Very dark grayish brown soil \\
\hline $8 a$ & $0-10 \mathrm{~cm}$ & $2.5 \mathrm{Y} 4 / 2$ & Dark grayish brown soil \\
\hline $8 b$ & $10-33 \mathrm{~cm}$ & $2.5 \mathrm{Y} 5 / 2$ & Light grayish brown soil \\
\hline 9 & $0-30 \mathrm{~cm}$ & $2.5 \mathrm{Y} 5 / 2$ & Light grayish brown soil \\
\hline 10 & $0-36 \mathrm{~cm}$ & $2.5 \mathrm{Y} 5 / 2$ & Light grayish brown soil \\
\hline 11 & $0-27 \mathrm{~cm}$ & $2.5 \mathrm{Y} 4 / 2$ & Dark grayish brown soil \\
\hline 12 & $0-30 \mathrm{~cm}$ & $2.5 \mathrm{Y} 4 / 2$ & Dark grayish brown soil with pebbles \\
\hline $13 a$ & $0-25 \mathrm{~cm}$ & $2.5 \mathrm{Y} 4 / 2$ & Dark grayish brown soil \\
\hline $13 b$ & $25-35 \mathrm{~cm}$ & $2.5 \mathrm{Y} 5 / 2$ & Grayish brown soil with many pebbles \\
\hline 14 & $0-35 \mathrm{~cm}$ & $2.5 \mathrm{Y} 3 / 2$ & Very dark grayish brown soil \\
\hline $15 \mathrm{a}$ & $0-25 \mathrm{~cm}$ & $2.5 Y 4 / 2$ & Dark grayish brown soil \\
\hline $15 b$ & $25-38 \mathrm{~cm}$ & $2.5 \mathrm{Y} 4 / 2$ & Dark grayish brown soil \\
\hline 16 & $0-32 \mathrm{~cm}$ & $2.5 \mathrm{Y} 4 / 2$ & Dark grayish brown soil with paper scrap \\
\hline
\end{tabular}




\section{REFERENCES CITED}

Bexar County, Texas

Spanish Deeds

County Clerk's Office, Bexar County

Courthouse, San Antonio, Texas.

Deed Records (DR)

County Clerk's Office, Bexar County

Courthouse, San Antonio, Texas.

Clark, J. W., Jr.

1978 Mission San José y San Miguel de Aguayo Archeological Investigation, December 1974. Texas Historical Commission, Office of the State Archeologist, Report 29.

Fox, A. A. and C. L. Highley

1985 History and Archaeology of the Hot Wells Hotel Site, 41 BX 237. Center for Archaeological Research, The University of Texas at San Antonio, Archaeological Survey Report 152.

Fox, D. E.

1970 Archeological Salvage at San José, December 1969, April and August 1970. Office of the State Archeologist, Special Report 3, Texas Historical Survey Committee, Austin.

Habig, M. A., O. F. M.

1968 San Antonio's Mission San José: State and National Historic Site, 1720-1968. Naylor Company, San Antonio, Texas, and Franciscan Herald Press, Chicago.

Hafernik, D. B., I. W. Cox, and A. A. Fox

1989 Archaeological Investigation of the San Juan Dam, 41 BX 266, Bexar County, Texas. Center for Archaeological Research, The University of Texas at San Antonio, Archaeological Survey Report 179.

Rivera, P. de

1730 Pedro de Rivera to the Viceroy, Sept. 30, 1730. In The San José Papers, Part I:1719-1791, Fr. B. Leutenegger, translator; Fr. M. A. Habig, compiler and annotator: 46-50. Old Spanish Missions Historical Research Library at San José Mission, San Antonio, Texas, 1978.
Santa Ana, B. F. de

1740 Fr. Benito Fernández de Santa Ana to Fr. Pedro del Barco, Feb. 20, 1740. In The San José Papers, Part I:1719-1791, Fr. B. Leutenegger, translator; Fr. M. A. Habig, compiler and annotator: 51-74. Old Spanish Missions Historical Research Library at San José Mission, San Antonio, Texas, 1978.

Schuetz, M. K.

1970 Excavation of a Section of the Acequia Madre in Bexar County, Texas, and Archeological Investigations at Mission San José in April 1968. Texas Historical Survey Committee, Archeological Report 19, Austin.

Scurlock, D., A. Benavides, Jr., D. Isham, and J. W. Clark, Jr.

1976 An Archeological and Historical Survey of the Proposed Mission Parkway, San Antonio, Texas. Office of the State Archeologist, Texas Historical Commission, Austin.

Valdéz, J.

1720 Report of Captain Juan Valdéz, March 13, 1720. In The San José Papers, Part I:1719-1791, Fr. B. Leutenegger, translator; Fr. M. A. Habig, compiler and annotator: 27-42. Old Spanish Missions Historical Research Library at San José Mission, San Antonio, Texas, 1978. 
